\title{
Clinical Management in Systemic Type Pseudohypoaldosteronism Due to SCNN1B Variant and Literature Review
}

\author{
(D) Gülin Karacan Küçükali1, (D) Semra Çetinkaya1, (D) Gaffari Tunç², (D) M. Melek Oğuz³, (D) Nurullah Çelik4, (D) Kardelen Yağmur Akkaş³, \\ (D) Saliha Şenel3 ${ }^{3}$ (i) Naz Güleray Lafcı ${ }^{5}$, (D) Şenay Savaş Erdeve ${ }^{1}$ \\ 1 University of Health Sciences Turkey, Dr. Sami Ulus Maternity, Child Health and Diseases Training and Research Hospital, Clinic of Pediatric \\ Endocrinology, Ankara, Turkey \\ 2 Sivas Cumhuriyet University Faculty of Medicine, Department of Child Health and Diseases, Division of Neonatalogy, Sivas, Turkey \\ 3 University of Health Sciences Turkey, Dr. Sami Ulus Maternity, Child Health and Diseases Training and Research Hospital, Clinic of Pediatric, \\ Ankara, Turkey \\ 4Sivas Cumhuriyet University Faculty of Medicine, Department of Child Health and Diseases, Division of Pediatric Endocrinology, Sivas, Turkey \\ 5 University of Health Sciences Turkey, Dr. Sami Ulus Maternity, Child Health and Diseases Training and Research Hospital, Clinic of Medical \\ Genetics, Ankara, Turkey
}

\section{What is already known on this topic?}

Pseudohypoaldosteronism is a life threatening disease due to serious salt loss. Differential diagnosis from other adrenal insufficencies is important because the treatments are different. Patient compliance is difficult due to the need for excessive amounts of oral treatments.

\section{What this study adds?}

We present a patient with a difficult diagnostic process due to hypertension. A novel variant resulting in a premature stop codon was detected in the patient. Clinical and laboratory features of all published cases with SCNN1B variant are reviewed.

\section{Abstract}

Systemic pseudohypoaldosteronism (PHA) is a rare, salt-wasting syndrome that is caused by inactivating variants in genes encoding epithelial sodium channel subunits. Hyponatremia, hyperkalemia, metabolic acidosis, increased aldosterone and renin levels are expected findings in PHA. Clinical management is challenging due to high dose oral replacement therapy. Furthermore, patients with systemic PHA require life-long therapy. Here we report a patient with systemic PHA due to SCNN1B variant whose hyponatremia and hyperkalemia was detected at the $24^{\text {th }}$ hour of life. Hyperkalemia did not improve with conventional treatments and dialysis was required. He also developed myocarditis and hypertension in follow-up. Challenges for diagnosis and treatment in this patient are discussed herein. In addition, published evidence concerning common features of patients with SCNN1B variant are reviewed.

Keywords: Systemic pseudohypoaldosteronism, hyponatremia, hyperkalemia, metabolic acidosis, epithelial sodium channel, SCNN1B

\section{Introduction}

Aldosterone is a mineralocorticoid hormone that provides sodium absorbtion and potassium secretion. Sodium crosses the apical membrane in the principal cells in kidney and enters the epithelial cell through the ion selective epithelial sodium channel (ENaC). Potassium is also secreted into the tight epithelium in the kidney. The ENaC is located in the apical membranes of sensitive tissues, such as the distal nephron, distal colon, salivary and sweat glands and creates a rate-limiting step in sodium reabsorption $(1,2)$. ENaC is a heteromultimeric protein consisting of three subunits, $\alpha, \beta$, $\gamma$ (3). ENaC subunits are encoded by the SCNN1A gene on chromosome 12p13, and the SCNN1B and $S C N N 1 G$ genes on chromosome 16p12.2-p12.1. 
Pseudohypoaldosteronism (PHA) is a salt wasting syndrome that develops due to variants in the mineralocorticoid receptor (MR) or ion channels in the kidney tubules. The estimated incidence of this rare disease is between $1 / 47,000$ and $1 / 80,000$, and its prevalence is $<1 / 1,000,000(4,5,6)$. PHA1 is divided into renal (PHA1A) and systemic (PHA1B) forms depending on mutation in the NR3C2 gene that codes the MR or in the SCNN1A, SCNN1B and SCNN1G genes that code ENaC subunits, respectively. In the systemic form, there is serious salt loss from the lung, colon, sweat and salivary glands, besides the kidney, and the symptoms begin in the neonatal period. Systemic PHA, which is inherited in an autosomal recessive fashion, results in life-threatening hyponatremia, hyperkalemia and metabolic acidosis. Plasma renin and aldosterone levels increase significantly, indicating end organ resistance. Treatment requires high doses of sodium replacement and potassium-lowering approaches. In this article, the clinical management of a patient with PHA due to an SCNN1B variant and the common features of patients with $S C N N 1 B$ variants are presented.

\section{Case Report}

The male patient was born at term by normal vaginal delivery with a birth weight of 3600 grams and was followed up in the neonatal intensive care unit due to respiratory distress. It was learned that hyponatremia and hyperkalemia were detected ( $\mathrm{Na} 118 \mathrm{mEq} / \mathrm{L}, \mathrm{K} 8 \mathrm{mEq} / \mathrm{L}$ ) at the $24^{\text {th }}$ hour of hospitalization. He received $6 \times 1 \mathrm{~g}$ salt, $4 \times 2 \mathrm{~g} / \mathrm{kg}$ calcium polystyrene sulfonate, $12 \times 1 \mathrm{~mL} / \mathrm{kg} 8.4 \%$ $\mathrm{NaHCO}_{3}$ and $12 \times 4 \mathrm{~mL} / \mathrm{kg} 3 \% \mathrm{NaCl}$ treatment during this period. He was subsequently referred to our clinic because of lack of response to treatments at the age of 1 month and 15 days. On physical examination, his weight was 4000 grams [-1.32 standard deviation score (SDS)], height was 55 $\mathrm{cm}(-0.34 \mathrm{SDS})$, and he did not have hyperpigmentation and any abnormality on genital examination. His daily weight gain was insufficient. His blood pressure was high at 110/80 $\mathrm{mmHg}\left(95^{\text {th }}\right.$ percentiles for systolic and diastolic blood pressure for this age group are 94/46 $\mathrm{mmHg}$ ). There was third degree consanguinity between the parents. His brother had died at the age of seven days with hyponatremia and hyperkalemia. On admission, Na concentration was 123 $\mathrm{mEq} / \mathrm{L}, \mathrm{K} 7.1 \mathrm{mEq} / \mathrm{L}$, blood $\mathrm{pH} 7.12$, and $\mathrm{HCO}_{3}$ was 10.8 $\mathrm{mmol} / \mathrm{L}$. Echocardiography was normal. He was diagnosed with congenital adrenal hyperplasia. Hydrocortisone and fludrocortisone treatments were started. Calcium gluconate, glucose-insulin infusion, $\mathrm{NaHCO}_{3}$ infusion, and salbutamol inhalation were administered for hyponatremia and hyperkalemia. Despite these interventions, hyponatremia persisted. Anti-hypertensive treatment was started for hypertension (0.1 $\mathrm{mg} / \mathrm{kg} /$ day amlodipine). Oral $2 \times 0.5$ grams of salt was also added to the treatment and the dose was gradually increased. The laboratory findings at admission to our clinic were: 17-hydroxyprogesterone 1.22 ug/L, dehydroepiandrosterone sulfate $241.8 \mu \mathrm{g} / \mathrm{dL}$, total testosterone $215.6 \mathrm{ng} / \mathrm{dL}$, adrenocorticotropic hormone $255 \mathrm{pg} / \mathrm{mL}$, cortisol $43.8 \mu \mathrm{g} / \mathrm{dL}$, renin $16.3 \mathrm{ng} / \mathrm{mL} /$ hour $(\mathrm{NR}=2.4-37)$, aldosterone $6.4 \mu \mathrm{g} / \mathrm{L} \quad(\mathrm{NR}=0.065-0.86)$, urine $\mathrm{Na} 134 \mathrm{mmol} / \mathrm{L}$, urine $\mathrm{K} 2 \mathrm{mmol} / \mathrm{L}$ (when blood $\mathrm{Na} 123 \mathrm{mEq} / \mathrm{L}$ and blood $\mathrm{K} 7.1 \mathrm{mEq} / \mathrm{L}$ ). The transtubular potassium gradient (TTKG) was 1.3, indicating very low renal potassium excretion. Based on the laboratory test results, hydrocortisone and fludrocortisone treatments were discontinued. Urinalysis, urine culture and renal ultrasonography were normal. During this process, hypertension continued. The diagnosis of systemic PHA was considered given that the patient was admitted with hyponatremia and hyperkalemia in the neonatal period, with high aldosterone level, increased urinary Na excretion, and decreased K excretion. When hyperkalemia did not respond to conventional treatments, including a trial of calcium polystyrene sulfonate at $1 \mathrm{~g} / \mathrm{kg} /$ dose in four doses, peritoneal dialysis was required. After three days of peritoneal dialysis, $\mathrm{K}$ decreased to $4.18 \mathrm{mEq} / \mathrm{L}$. Electrolyte values of the patient were kept in the normal range with $6 \times 1 \mathrm{~g}$ of oral salt and $4 \times 3 \mathrm{~g}$ of anti-potassium treatment. The patient had fever during the follow up and despite subsequent normalization of body temperature, tachycardia persisted. The patient was diagnosed with myocarditis due to an increase in acute phase reactants, troponin 1 level and electrocardiographic findings. Myocarditis findings regressed on the tenth day. However, the cause of hypertension could not be explained and was thought to be related to the salt treatment. Then his blood pressure returned to normal ranges and amlodipine and propranalol treatments were discontinued on the fourteenth day. The Sanger sequencing analysis of the SCNN1A gene, which is the most common gene to carry pathogenic variants in systemic PHA type 1B, was found to be normal. In subsequent Illumina MiSeq sequencing, a homozygous c. 978 C > A (p.Tyr326Ter) variant was detected in the sixth exon of the SCNN1B gene (NM_000336). After oral salt (6x1 g) and antipotassium ( $4 \times 3 \mathrm{~g}$ ) administration, the patient had normal electrolyte values and was discharged. One month after discharge, during a period of infection, the patient had to be hospitalized again due to the loss of oral intake and salt wasting crisis. At the last follow-up, the patient was seven months old, his weight was $7.3 \mathrm{~kg}(-1.3 \mathrm{SDS})$, height was $68 \mathrm{~cm}(-0.83 \mathrm{SDS})$ and blood pressure was 80/35 $\mathrm{mmHg}\left(50^{\text {th }}\right.$ percentile). His growth and development was 
appropriate for the age with the current treatments $(6 \times 1 \mathrm{~g}$ oral salt, $4 \times 3 \mathrm{~g}$ calcium polystyrene sulfonate and $4 \times 2 \mathrm{~mL}$ $\mathrm{NaHCO}_{3}$ ). Clinical follow-up continues.

\section{Discussion}

Systemic PHA type 1 is a rare life-threatening disease. Clinical manifestations are similar to other adrenal gland insufficiencies, such as congenital adrenal hyperplasia, hypoaldosteronism, and secondary PHA. The clinical presentation is characterized by insufficient weight gain, vomiting, and dehydration $(4,6,7,8)$. Our patient had normal genitalia with hyponatremia and hyperkalemia. Hydrocortisone and fludrocortisone treatments were started until adrenal androgen results were obtained. Since adrenal hormone levels were normal in the follow-up, the patient was diagnosed with PHA1B. In the differential diagnosis of our patient, transient aldosterone resistance secondary to urinary tract infection was also considered (4), and this diagnosis was ruled out when urinalysis, urine culture and renal ultrasonography were normal. Elevated aldosterone level accompanying hyponatremia and hyperkalemia supported resistance to aldosterone in the kidney and directed the treatment of our patient.

To date, more than 40 variants have been reported in the genes encoding $\mathrm{ENaC}$ subunits (9), and these variants have most often been found in the gene encoding the alpha subunit. Eleven variants have been reported in the gene encoding the beta subunit (Table 1). Consequently, we first investigated the SCNN1A gene encoding the alpha subunit, but when no pathogenic variant was found, the SCNN1B gene was sequenced. In this patient, a novel c.978 C > A (p.Tyr326Ter) homozygous variant was detected, presumably leading to a premature stop codon in the SCNN1B gene. This variant has not been previously reported in the literature or in the GnomaD database including genome data from healthy individuals, and is anticipated to be a pathogenic change by Variant Taster, one of the in silico assessment tools used to predict pathogenicity of a variant. In addition, this change has been considered pathogenic according to the criteria of American College of Medical Genetics guidelines 2015 (PVS1, PM2, PP3).

The SCNN1B gene, consisting of 13 exons, encodes a transmembrane protein with two transmembrane segments with 640 amino acids (Figure 1) (7). The detected variant is located in the extracellular region of the protein, and, it is predicted to cause loss of function by creating an early stop codon, presumably resulting in nonsense mediated decay at the mRNA level.

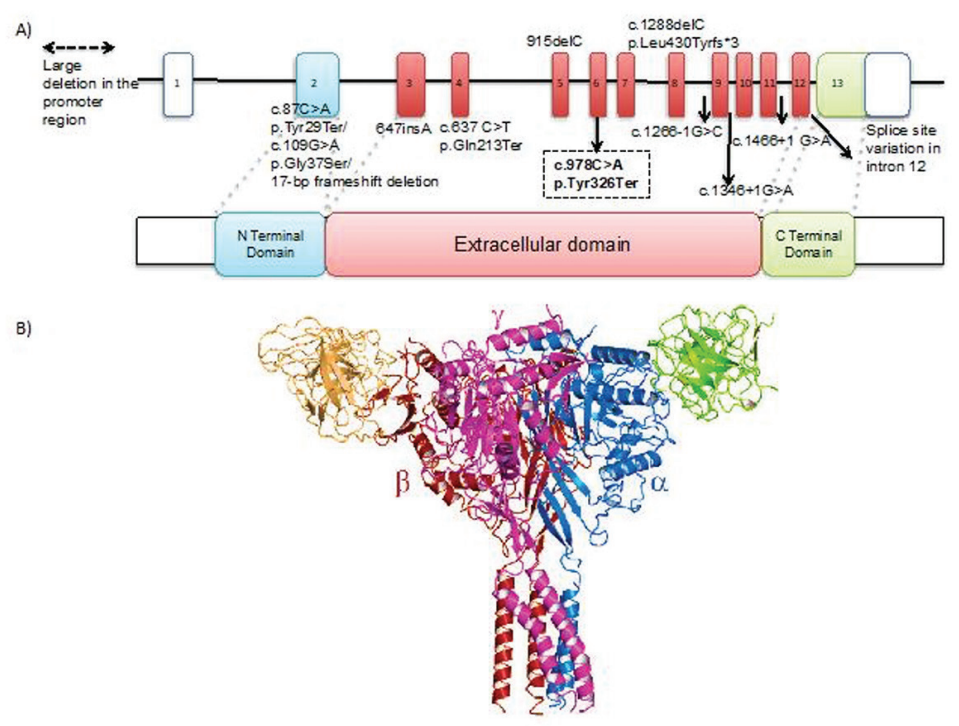

Figure 1. A) 3-D structure of the SCNN1B protein (PDB 6BQN) black arrow indicates the mutated position on the protein. $B$ ) Close up view of the tyrosine aminoacid at the $326^{\text {th }}$ position

To date, 11 variants with PHA due to $S C N N 1 B$ variants have been reported (Table 1). These cases were diagnosed in infancy with classical findings. On follow-up, two case died due to salt wasting crisis $(6,8)$. In four cases, there were skin manifestations, such as dry skin, severe eczema, bullous dermatitis and hidradenitis suppurativa $(7,10,11)$. Recurrent lung infections developed in four cases $(7,11,12,13)$ and gastrostomy was required in four cases due to the salt wasting $(8,10,11,13)$. Pulmonary hypertension developed in one case during follow-up (11). Apart from the case presented here, no other developed viral myocarditis and hypertension was encountered during attacks.

Both urgent and long-term treatments of PHA involve many challenges. Hyperkalemia can be life threatening due to the risk of cardiac arrhythmia. In the literature and similar to our case, there have been previous reports of peritoneal dialysis to correct hyperkalemia $(7,14,15,16)$. Cases requiring gastrostomy due to difficulties in continuing oral treatment have also been reported $(4,5,8,10,11,13,17)$. Patients with PHA are prone to pulmonary infections due to a decrease in sodium-dependent fluid absorption in the lungs. Rapid decompensation may occur during episodes of infection or when oral intake is impaired. After the electrolyte balance was achieved in the follow-up of our patient, salt wasting reccurred due to intervening viral myocarditis and, during this period, treatments were given via nasogastric tube.

\section{Conclusion}

Systemic PHA is a challenging disease to manage, with severe salt wasting that starts in the neonatal period. In 


\section{Table 1. Clinical and laboratory features of this and other cases with SCNN1B mutation in the literature thoma}

\begin{tabular}{|c|c|c|c|c|c|c|c|c|c|c|c|}
\hline & 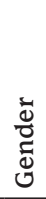 & 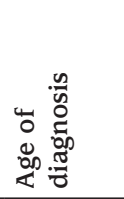 & z & $\begin{array}{r}\frac{\vec{\sigma}}{\sigma} \\
\times \stackrel{\Xi}{E}\end{array}$ & 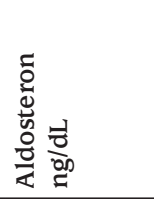 & 氙 & 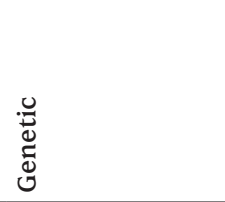 & 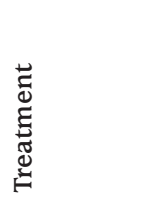 & 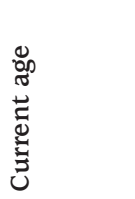 & 胥 & 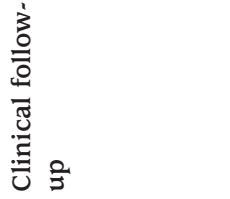 \\
\hline 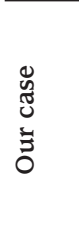 & M & $\begin{array}{l}1 \text { month } \\
25 \text { days }\end{array}$ & 123 & 7.1 & 640 & 16.3 & $\begin{array}{l}\text { c.978C > A } \\
\text { (p.Tyr326Ter) } \\
\text { (E6) } \\
\text { Homozygous }\end{array}$ & $\begin{array}{l}\mathrm{NaCl}, \\
\mathrm{NaHCO}_{3}, \\
\text { sodium } \\
\text { polystyrene } \\
\text { sulphate }\end{array}$ & $\begin{array}{l}7 \text { months } \\
\text { old }\end{array}$ & $\begin{array}{l}\text { Myocarditis } \\
\text { and } \\
\text { hypertension }\end{array}$ & $\begin{array}{l}\text { Once experienced } \\
\text { salt wasting } \\
\text { crisis during } \\
\text { infection, now } \\
\text { his development } \\
\text { is appropriate for } \\
\text { age }\end{array}$ \\
\hline 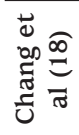 & - & 19 days & 133 & 8.2 & * & - & $\begin{array}{l}\text { c.109G > A } \\
\text { (p.Gly37Ser) } \\
\text { (E2) } \\
\text { Homozygous }\end{array}$ & - & - & - & - \\
\hline 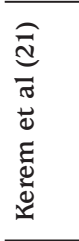 & $\mathrm{F}$ & - & - & - & - & - & $\begin{array}{l}\text { Two frame shift } \\
\text { variations } \\
647 \text { insA } \\
\text { (E3)/915delC } \\
\text { (E5) } \\
\text { Compound } \\
\text { heterozygous }\end{array}$ & - & 18 years & $\begin{array}{l}\text { High serum IgE } \\
\text { concentration, } \\
\text { normal } \\
\text { spirometry } \\
\text { and chest } \\
\text { radiography }\end{array}$ & \\
\hline 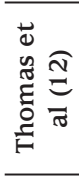 & - & 4 days & 127 & 10.2 & 1.281 & 235.5 & $\begin{array}{l}\text { Large } \\
\text { homozygous } \\
\text { deletion in the } \\
\text { promoter region } \\
\text { of of } \beta \mathrm{ENaC}\end{array}$ & $\begin{array}{l}\mathrm{NaCl}, \\
\mathrm{NaHCO}_{3}, \\
\text { sodium } \\
\text { polystyrene } \\
\text { sulphate } \\
\end{array}$ & $\begin{array}{l}7 \text { years } \\
\text { old }\end{array}$ & $\begin{array}{l}\text { Recurrent lung } \\
\text { infection }\end{array}$ & $\begin{array}{l}\text { There is a } \\
\text { decrease in the } \\
\text { frequency of lung } \\
\text { infections }\end{array}$ \\
\hline 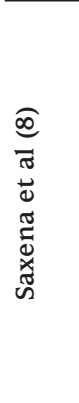 & M & 7-8 days & $<120$ & $8.5-10.5$ & $>1440$ & - & $\begin{array}{l}1669+1 G>A \\
\text { splice site } \\
\text { mutation in } \\
\text { intron } 12, \\
\text { Homozygous }\end{array}$ & $\begin{array}{l}\mathrm{NaCl}, \\
\text { kayexalate }\end{array}$ & - & - & $\begin{array}{l}\text { Recurrent salt- } \\
\text { wasting crisis } \\
\text { in newborn } \\
\text { and infancy, } \\
\text { gastrostomy } \\
\text { was required, } \\
\text { his growth and } \\
\text { development was } \\
\text { normal but he } \\
\text { died at the age } \\
\text { of } 6.5 \text { year after } \\
\text { cardiac arrest }\end{array}$ \\
\hline 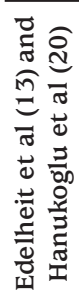 & M & 6 days & 135 & 5.9 & $39.6-248.7$ & $>50$ & $\begin{array}{l}1669+1 G>A \\
\text { splice site } \\
\text { mutation in } \\
\text { intron } 12, \\
\text { Homozygous }\end{array}$ & $\begin{array}{l}\mathrm{NaCl}, \\
\text { kayexalate }\end{array}$ & $\begin{array}{l}7 \text { years } \\
\text { old }\end{array}$ & $\begin{array}{l}\text { Persistent } \\
\text { clear nasal } \\
\text { discharge, } \\
\text { frequent lower } \\
\text { respiratory } \\
\text { infections and } \\
\text { failure to thrive }\end{array}$ & $\begin{array}{l}\text { Recurrent salt- } \\
\text { wasting crisis, } \\
\text { gastrostomy was } \\
\text { performed at } 14 \\
\text { months of age }\end{array}$ \\
\hline 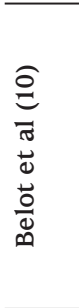 & $\mathrm{F}$ & 6 days & 126 & 6.8 & 1.627 & 1335 & $\begin{array}{l}\text { c.637 C > T } \\
\text { (p.Gln213Ter) } \\
\text { (E4), } \\
\text { Homozygous }\end{array}$ & - & $\begin{array}{l}3 \text { years } \\
\text { old }\end{array}$ & $\begin{array}{l}\text { Bullous } \\
\text { dermatitis }\end{array}$ & $\begin{array}{l}\text { During follow-up, } \\
\text { gastrostomy was } \\
\text { opened, normal } \\
\text { development at } \\
\text { the age of } 3 \text { but } \\
\text { still experiencing } \\
\text { diarrhea and } \\
\text { respiratory } \\
\text { distress attacks }\end{array}$ \\
\hline 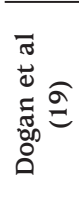 & $\mathrm{M}$ & 3 days & 125 & 9 & 946 & 140 & $\begin{array}{l}\text { c. } 1266-1 \mathrm{G}>\mathrm{C} \\
\text { splice site } \\
\text { mutation } \\
\text { in intron } 8, \\
\text { Homozygous }\end{array}$ & $\begin{array}{l}\mathrm{NaCl}, \\
\mathrm{NaHCO}_{3}, \\
\text { sodium } \\
\text { polystyrene } \\
\text { sulphate }\end{array}$ & $\begin{array}{l}3,5 \text { years } \\
\text { old }\end{array}$ & $\begin{array}{l}\text { Vomiting, poor } \\
\text { feeding }\end{array}$ & $\begin{array}{l}\text { Short stature, } \\
\text { decrease in } \\
\text { dehydration } \\
\text { attacks and in } \\
\text { hospitalization } \\
\text { with age }\end{array}$ \\
\hline
\end{tabular}




\begin{tabular}{|c|c|c|c|c|c|c|c|c|c|c|c|}
\hline 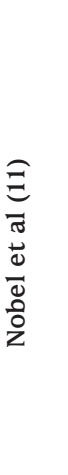 & $\mathrm{F}$ & $\begin{array}{l}2-3 \\
\text { weeks }\end{array}$ & 135 & 5,1 & 2.800 & 190 & $\begin{array}{l}\text { c. } 1288 \text { delC } \\
\text { (p.Leu430 } \\
\text { Tyrfs*3) } \\
\text { (E9)/c. } 1466+1 \\
\text { G > A splice site } \\
\text { mutation in intron } \\
11 \\
\text { Compound } \\
\text { heterozygous }\end{array}$ & & 32 years & $\begin{array}{l}\text { Myalgia, } \\
\text { hidradenitis } \\
\text { suppurativa, } \\
\text { pulmoner } \\
\text { hypertension }\end{array}$ & $\begin{array}{l}\text { Continuous } \\
\text { hospitalization } \\
\text { from } 2 \text { weeks } \\
\text { to } 2 \text { years and } \\
\mathrm{NaCl} \mathrm{NaHCO}_{3} \\
\text { and potassium } \\
\text { chelation } \\
\text { support with } \\
\text { gastrostomy tube } \\
\text { up to } 3.5 \text { years } \\
\text { old, recurrent } \\
\text { episodes of } \\
\text { chronic bronchitis } \\
\text { during childhood }\end{array}$ \\
\hline 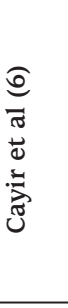 & M & 9 days & 106 & 11,8 & 317.5 & 98.2 & $\begin{array}{l}\text { c.87C > A } \\
\text { (p.Tyr29Ter) } \\
\text { (E2)/ } \\
\text { c.1346+1G > A } \\
\text { splice site } \\
\text { mutation in } \\
\text { intron } 9 \\
\text { Compound } \\
\text { heterozygous }\end{array}$ & $\begin{array}{l}\mathrm{NaCl}, \\
\text { sodium } \\
\text { polystyrene } \\
\text { sulphate }\end{array}$ & - & - & $\begin{array}{l}\text { During the follow } \\
\text { up had seven salt } \\
\text { wasting crisis and } \\
\text { died in the last } \\
\text { crisis at } 6 \text { months } \\
\text { of age }\end{array}$ \\
\hline 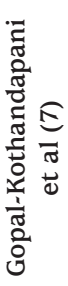 & $\mathrm{F}$ & 1 day & 128 & 7.8 & 64.7 & - & $\begin{array}{l}\text { c. } 1542+1 G>A \\
\text { splice site } \\
\text { mutation in } \\
\text { intron } 12\end{array}$ & $\begin{array}{l}\mathrm{NaCl}, \\
\mathrm{NaHCO}_{3}, \\
\text { sodium } \\
\text { resonium }\end{array}$ & $\begin{array}{l}8 \text { years } \\
\text { old }\end{array}$ & Severe eczema & $\begin{array}{l}\text { Recurrent } \\
\text { electrolyte } \\
\text { imbalances }\end{array}$ \\
\hline 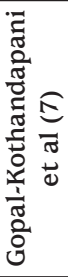 & $\mathrm{M}$ & 8 days & 113 & 11 & 600 & - & $\begin{array}{l}\text { 17-bp frameshift } \\
\text { deletion in } \\
\text { exon } 2\end{array}$ & $\begin{array}{l}\mathrm{NaCl}, \\
\mathrm{NaHCO}_{3}, \\
\text { sodium } \\
\text { resonium }\end{array}$ & $\begin{array}{l}14 \text { years } \\
\text { old }\end{array}$ & Dry skin & $\begin{array}{l}\text { Peritoneal dialysis } \\
\text { need at the first } \\
\text { application, } \\
\text { frequent lung } \\
\text { infection }\end{array}$ \\
\hline Plasm & & רcer & sta & g/ & the & & & & & & \\
\hline
\end{tabular}

this disease, life-threatening arrhythmias can be seen due to recurrent salt wasting and severe hyperkalemia. PHA1B can be confused with congenital adrenal hyperplasia. If a patient with hyperkalemia has hyponatremia, elevated urinary sodium excretion and low TTKG, mineralocorticoid resistance/deficiency should be considered. Treatment compliance is difficult due to the need for high dose oral salt and anti-potassium treatment. Long-term followup and treatment of these patients should careful, as the patients are frequently non-compliant with treatment and the frequency of rapid decompensation is high, especially during periods of infection.

\section{Ethics}

Informed Consent: Written informed consent was obtained from the parents.

Peer-review: Externally peer-reviewed.

\section{Authorship Contributions}

Surgical and Medical Practices: Gülin Karacan Küçükali, Semra Çetinkaya, Gaffari Tunç, M. Melek Oğuz, Nurullah Çelik, Kardelen Yağmur Akkaş, Saliha Şenel, Naz Güleray Lafc1, Şenay Savaş Erdeve, Concept: Gülin Karacan Küçükali, Semra Çetinkaya, M.Melek Oğuz, Saliha Şenel, Şenay Savaş Erdeve, Design: Gülin Karacan Küçükali, Naz Güleray Lafc1, Şenay Savaş Erdeve, Data Collection or Processing: Gülin Karacan Küçükali, Semra Çetinkaya, Gaffari Tunç, M. Melek Oğuz, Nurullah Çelik, Kardelen Yağmur Akkaş, Saliha Şenel, Naz Güleray Lafcı, Şenay Savaş Erdeve, Analysis or Interpretation: Gülin Karacan Küçükali, Semra Çetinkaya, M. Melek Oğuz, Saliha Şenel, Naz Güleray Lafcı, Şenay Savaş Erdeve, Literature Search: Gülin Karacan Küçükali, Şenay Savaş Erdeve, Naz Güleray Lafcı, Writing: Gülin Karacan Küçükali, Semra Çetinkaya, Şenay Savaş Erdeve, Naz Güleray Lafc1. 
Financial Disclosure: The authors declared that this study received no financial support.

\section{References}

1. Rossier BC. The epithelial sodium channel (ENaC) and the control of blood pressure. J Am Soc Nephrol 1997;8:980-992. Epub 2013 Dec 12

2. Garty H, Palmer LG. Epithelial sodium channels: function, structure, and regulation. Physiol Rev 1997;77:359-396.

3. Canessa CM, Schild L, Buell G, Thorens B, Gautschi I, Horisberger JD, Rossier BC. Amiloride-sensitive epithelial $\mathrm{Na}+$ channel is made of three homologous subunits. Nature 1994;367:463-467.

4. Amin N, Alvi NS, Barth JH, Field HP, Finlay E, Tyerman K, Frazer S, Savill G, Wright NP, Makaya T, Mushtag T. Pseudohypoaldosteronism type 1: clinical features and management in infancy. Endocrinol Diabetes Metab Case Rep 2013;2013:130010. Epub 2013 Aug 30

5. Kala Ahluwalia, Dasouki M, Lennon A. Phenotypic variation of autosomal recessive pseudohypoaldosteronism type 1: a case in point. Clin Case Rep 2014;2:326-330. Epub 2014 Sep 15

6. Cayir A, Demirelli Y, Yıldız D, Kahveci H, Yaralı O, Kurnaz E, Vuralli D, Demirbilek H. Systemic pseudohypoaldosteronism type 1 due to 3 novel mutations in SCNN1A and SCNN1B genes. Horm Res Paediatr 2019;91:175-185. Epub 2019 Apr 24

7. Gopal-Kothandapani JS, Doshi AB, Smith K, Christian M, Mushtaq T, Banerjee I, Padidela R, Ramakrishnan R, Owen C, Cheetham T, Dimitri P. Phenotypic diversity and correlation with the genotypes of pseudohypoaldosteronism type 1. J Pediatr Endocrinol Metab 2019;32:959-967.

8. Saxena A, Hanukoglu I, Saxena D, Thompson RJ, Gardiner RM, Hanukoglu A. Novel mutations responsible for autosomal recessive multisystem pseudohypoaldosteronism and sequence variants in epithelial sodium channel $\alpha-, \beta-, \gamma$ - subunit genes. J Clin Endocrinol Metab 2002;87:3344-3350.

9. Nur N, Lang C, Hodax JK, Quintos JB. Systemic pseudohypoaldosteronism type I: A case report and review of the literature. Case Rep Pediatr 2017;2017:7939854. Epub 2017 Apr 18

10. Belot A, Ranchin B, Fichtner C, Pujo L, Rossier BC, Liutkus A, Morlat C, Nicolino M, Zennaro MC, Cochat P. Pseudohypoaldosteronisms, report on a 10- patient series. Nephrol Dial Transplant 2008;23:1636-1641.

11. Nobel YR, Lodish MB, Raygada M, Rivero JD, Faucz FR, Abraham SB, Lyssikatos C, Belyavskaya E, Stratakis CA, Zilbermint M. Pseudohypoaldosteronism type 1 due to novel variants of SCNN1B gene. Endocrinol Diabetes Metab Case Rep 2016;2016:150104. Epub $2016 \operatorname{Jan} 7$

12. Thomas CP, Zhou J, Liu KZ, Mick VE, MacLaughlin E, Knowles M. Systemic pseudohypoaldosteronism from deletion of the promoter region of the human $\beta$ epithelial $\mathrm{Na}+$ channel subunit. Am J Respir Cell Mol Biol 2002;27:314-319.

13. Edelheit O, Hanukoglu I, Gizewska M, Kandemir N, TenenbaumRakover Y, Yurdakök M, Zajaczek S, Hanukoglu A. Novel mutations in epithelial sodium channel (ENaC) subunit genes and phenotypic expression of multisystem pseudohypoaldosteronism. Clin Endocrinol (Oxf) 2005;62:547-553

14. Güran T, Degirmenci S, Bulut IK, Say A, Riepe FG, Güran Ö. Critical points in the management of pseudohypoaldosteronism type 1. J Clin Res Pediatr Endocrinol 2011;3:98-100. Epub 2011 Jun 8

15. Saravanapandian N, Paul S, Matthai J. Pseudohypoaldosteronism type 1: a rare cause of severe dyselectrolytemia and cardiovascular collapse in neonates. J Clin Neonatol 2012;1:224-226.

16. Sharma R, Pandey M, Kanwal SK, Zennaro MC. Pseudohypoalsteronism type 1: management issues. Indian Pediatr 2013;50:331-333.

17. Önder A, Çetinkaya S, Kara C, Zenciroğlu A, Aycan Z. Multisystemic severe form pseudohypoaldosteronism: can gastrostomy be useful in management? Turkish J Pediatr Dis 2016;2:134-136.

18. Chang SS, Grunder S, Hanukoglu A, Rösler A, Mathew PM, Hanukoglu I, Schild L, Lu Y, Shimkets RA, Nelson-Williams C, Rossier BC, Lifton RP. Mutations in subunits of the epithelial sodium channel cause salt wasting with hyperkalemic acidosis, pseudohypoaldosteronism type 1 . Nat Genet 1996;12:248-253.

19. Dogan CS, Durmaz, Parlak M, Akan M, Akcurin S, iffet B, Afig B. A novel splice site mutation of the beta subunit gene of epithelial sodium channel (ENaC) in one Turkish patient with systemic form of pseudohypoaldosteronism type 1. J Pediatr Endocrinol Metab 2012;25:1035-1039.

20. Hanukoglu A, Edelheit O, Shriki Y, Gizewska M, Dascal N, Hanukoglu I. Renin-aldosteron response, urinary $\mathrm{Na} / \mathrm{K}$ ratio and growth in pseudohypoaldosteronism patients with mutations in epithelial sodium channel $(\mathrm{ENaC})$ subunit genes. J Steroid Biochem Mol Biol. 2008;111:268-274. Epub 2008 Jun 26

21. Kerem E, Bistritzer T, Hanukoglu A, Hofmann T, Zhou Z, Bennett W, MacLaughlin E, Barker P, Nash M, Quittell L, Boucher R, Knowles MR. Pulmonary epithelial sodium-channel dysfunction and excess airway liquid in pseudohypoaldosteronism. N Engl J Med 1999;341:156-162. 